\title{
Evaluation of community economic building movement policy in East Flores Regency
}

Dominikus Fernandez ${ }^{1 *}$, Rikhardus Seran Klau ${ }^{2}$, Adriana Rodina Fallo ${ }^{3}$

Nusa Cendana University ${ }^{1,2,3}$

leoniodasilva7@gmail.com

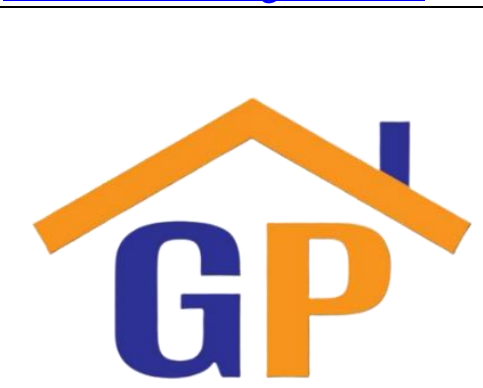

Article History

Received on 20 October 2020

Revised on 18 December 2020

Accepted on 21 December 2020

\begin{abstract}
Purpose: The purpose of this study is to evaluate the Policy of Community Economic Building Movement in East Flores Regency. Research methodology: The research method used in this research is a descriptive research method with a qualitative approach.

Results: The findings in this study are that there are many deficiencies in terms of both content of policy and policy implementation.
\end{abstract}

Limitations: this research only discusses and evaluates the policies of community economic development movements in the East Flores district.

Contribution: This research becomes scientific information for public administration science.

Keywords: Evaluation, Empowerment

How to cite: Fernandez, D., Klau, R. S., Fallo, A. R. (2019). Evaluation of community economic building movement policy in East Flores Regency. Annals of Management and Organization Research, 1(2), 123-140.

\section{Introduction}

Welfare, public services and people's prosperity are the products of the country's overall administrative system including the administration of local government. One of the strategies that is in order to accelerate and improve the welfare, public services, and prosperity of the people in the region today is generally through economic empowerment policy in the form of the creation of space /share to participate in various development activities in accordance with its capabilities and skills.

In the context of regional autonomy, although Law No. 23 of 2014 on Local Government has laid out the principle of fiscal decentralization, but the Local Government to date continues to struggle with various issues such as development disparities (interregional and interregional), poverty, unemployment, SMEs, maintaining or maintaining sustainable natural resources sustainability, public services, governance, and so on.

This general issue, has encouraged the Local Government, in this context the Flores District Government took strategic steps namely by setting policies (programs) to build the community economy (Golden Gate; East Flores Regent Regulation No. 5/2013 on Technical Instructions for Implementation of Community Economic Building Movement Program). Its implementation has two general objectives: (1) tackling poverty, and (2) improving people's well-being. These two general objectives are further described into two specific objectives: (a) increasing people's per capita income, (b) creating employment opportunities; while the target is a) the institutional development of cooperatives/microfinance institutions in villages/villages, and b) communities in villages/villages are splaced in productive economic business groups.

In order to realize this program, since 2013 has been allocated Rp.250 million per target village Table 1

Number of Villages, Number of Groups and Number of Group Members and Number of Gold Gate Program Funds

\begin{tabular}{|c|l|c|c|c|c|}
\hline No. & Year & $\begin{array}{c}\text { Number of } \\
\text { Villages }\end{array}$ & $\begin{array}{c}\text { Number of } \\
\text { Villages }\end{array}$ & $\begin{array}{c}\text { Number of Group } \\
\text { Members }\end{array}$ & $\begin{array}{c}\text { Numver of Fund } \\
\text { (Rp.) }\end{array}$ \\
\hline
\end{tabular}




\begin{tabular}{|l|l|l|l|l|l|}
\hline 1 & 2017 & 19 & 181 & 1.288 & 4.750 .000 .000 \\
\hline 2 & 2018 & 45 & 381 & 2.360 & 11.250 .000 .000 \\
\hline 3 & 2019 & 41 & 247 & 1.587 & 10.250 .000 .000 \\
\hline
\end{tabular}

Source: BPMPD East Flores Regency, 2019.

The information that can be conveyed in relation to this table 1 is that judging by the number of groups and the number of members each year experienced a decrease especially with regard to the type of business of the group. Based on interviews with the Head of BPMPD East Flores Regency, it was said that the decrease was due to several things, including: a) some members of the target group have not been able to absorb the entire installment deposit, b) some members of the group do not carry out the activities as proposed, c) about $30 \%$ of the target village has not been able to absorb the funds entirely $(100 \%)$, d) quite a lot of target groups whose members are no longer willing to be members of the business group, e) there is no business network for both supply and products, f) most members of the business group do not yet understand this policy as an economic policy and they always associate with traditional patterns of behavior. Some of the above points may comment that this condition occurs as a result of not obtaining something (certain value) by members of the group or the group since it is involved in this policy.

The emergence of various problems in a policy is common in government administration. The success or failure of policy implementation can be influenced by various factors and the parties involved must examine these factors carefully. To be able to identify problems that occur in a policy, it is necessary to conduct an evaluation that assesses the implementation of the policy in depth. Do not forget that the evaluation must be based on valid and reliable science. Therefore, based on the problems that have been described in the previous paragraphs and the importance of an evaluation based on science, the authors conducted this research with the title Evaluation of Community Economic Development Movement Policy in East Flores Regency.

\section{Literature review}

Jati research, et al. (2015) titled Implementation of Innovation program movement building community economy (Golden Gate) in increasing small micro-business income in East Flores Regency, one of the concluding that the inhibitory factor of the implementation of this program is the lack of socialization and preparation of the target group of the program as well as the absence of training before the distribution of funds; the implementation performance of innovation program $\pm 58 \%$ of the result is felt by the target program, revenue increases after the funding assistance, but there are still installment arrears of Rp. 551,081,022 it is recommended that business management improvement at the village and UPK level in addition to training before the distribution of relief funds. The results of the study: Evaluation of the Implementation of Community Economic Development Movement Program in East Flores Regency (BPMPD of East Flores Regency and UNDANA Research Institute, 2015) mentioned (a) reviewed from the adequacy indicator as an indicator of the process - the results of the implementation of the Golden Gate program are considered to be low in encouraging the achievement of optimization of the objectives of the program coordination between teams at each level of the implementing organization, program socialization, mentoring and monitoring seems still low, (b) effectiveness as an indicator of the process - the results are considered ineffective and greatly influence the achievement of the program objectives especially related directly to poverty reduction. The results of this study show that there has not been a single organizational unit that optimally synergizes in both input level, process and policy output.

The observations that researchers encountered while conducting research with Jati, et al (2015): a) in some villages of members of the business grant recipients turned out instead to try but act as a loan shark and some members of the group tried on other types of businesses instead of on the proposed type of business, b) there are several groups (fish baskets, agricultural businesses, commodity collectors doing their business activities outside the village --- this occurs due to the absence of a business network, c) loan installments are not derived from business results but are loans from other parties, d) economic efforts carried out by members are often related and or in conjunction with traditional rituals/ceremonies. Some of the things that are conveyed above can be said that this policy is impressed as a project, when in fact it should take action policies continuum. 


\subsection{Policy evaluation variables}

There are six variables commonly used to evaluate a policy. The six variables:

a. Input Variables: i.e. everything needed for policy implementation to take place and produce output. Related to this variable the results of research presented by Sartika on the Evaluation of Fisher Empowerment Policy that there are several factors inhibiting the achievement of goals and policy results are policy concepts that show the basic obscurity of the thought of the birth of the policy of empowerment of fishermen. In this perspective Sartika emphasizes the importance of understanding the vision, mission, objectives, goals and targets of each community empowerment program. In relation to policy input variables; Jati research results, et al (2015) mentioned the low innovation of the implementation of community economic building policies in East Flores Regency is also caused by the inconscion of implementors in this case related agencies to the objectives and results of this condition resulted in low coordination between the agencies which further led to the business group's inconscionation towards the objectives of economic empowerment of the community; also seen in the lack of monitoring and supervision activities on policies implemented.

b. Process Variables: generally the organization formulates the size of the activity both in terms of speed, accuracy and accuracy of the implementation of the activity. Usually these process variables are related to the size of efficiency, effectiveness as well as economy. A process variable is a variable that determines the outcome of a policy. The results of Moenardy's research, et al (2015) show that the need to improve financial management literacy of both individuals and groups, the need for technical improvement by relevant agencies, the need for entrepreneurial mentoring and training, and the improvement of group containers into microreduction institutions. In almost the same view Sartika (2015) mentions that the importance of the development of group independence, the prosecution of obedience/compliance of group members as well as the training of members is mainly related to business management.

c. Output Variable: It is something that can be achieved directly from an activity that can be physical or nonphysical. This variable is used to assess the progress of the activity. Activity result variables are an important component in measuring and assessing policy objectives. Output is often interpreted as the fulfillment of the function of an object according to its specifications.

The results of Postkarina research, et al, (2007) on Evaluation of Market Management Policy in Bandung stated that the output of market management policy is not in accordance with the policy objectives. This is demonstrated by the increasingly marginalization of traditional traders to access the market as well as market managers who feel never involved in the process of structuring the market.

\subsection{Cultural and social values}

Cultural values are agreed values and embedded in a society, cultural values are already attached to groups or individuals in a society that is in an area. Pelly (1994:41) defined cultural values as a general, organized concept, affecting nature-related behavior, human standing in nature, people's relationships with people and about things that are wanting and not to be concerned with people's relationships with the environment and fellow human beings. Cultural values are abstract, which are used as guidelines and general principles in acting and behaving. In almost the same view, Marpaung (2000) said that in the development, development of cultural application in life, the development of values inherent in society that regulate harmony, harmony, and balance. These values are conceptual as cultural values. Furthermore, pointing to the rejection of the above statement, it can be said that each individual in carrying out his or her social activities is always based and guided by existing values or systems and lives in society itself. That means those values very much influence human actions and behaviors, whether individually, group or society as a whole about good - bad, right wrong - appropriate or inappropriate. Furthermore, values can form attitudes and morals as a basis for conduct. 
In some studies, social values have always been associated with traditional rituals. Traditional rituals are an activity that a group of people does to worship the ancestors in order to get a blessing. In the view of Koentjaraningrat (1985) Ritual is an ordinance in a ceremony or a sacred act performed by a group of religious people characterized by various elements and components, namely the time, places where the ceremony is performed, tools in the ceremony, and people who carry out the ceremony. Bustanuddin (2007) sees rituals or rites performed with the aim of obtaining blessings or sustenance from a work such as the ceremony of rejecting bala (disaster) and ceremony due to changes or cycles in human life such as birth, marriage and death. Meanwhile, according to Hilma Hadikusuma (2003:3) customs are customs as rules determined by ancestors. In this case the custom contains the meaning of the rules of customs rules that apply from ancient times to the present, these rules of habit are generally not accessible. Tradition is a reflection of the personality of a nation that is the incarnation of the soul in question for centuries; every nation in the world has a different customs to other nations. Tradition is the most important element in the community or region that ware considered be respecting and adhering to by the supporting community because the community regulates a discipline that binds norms and behaviors in the community.

The results of Fernandez and Jati 's research (2010) on Keba Bai Pito's Indigenous Community Institutions Attitude towards Village Government Structure according to PP/72 year 2005 on Villages; concluded several things: (a) indigenous peoples in general have confidence to benefit in improving the quality of life if village governance is based on local indigenous systems and rules formalized in addition to compliance with village heads, (b) the level of trust of indigenous communities towards formal institution is high due to the understanding that by engaging fully in the process of selection of village heads personal and family needs are met, facilitating the relationship between members of the indigenous community and with the village chief, (c) The indigenous institution community believes that the habits of living with indigenous communities and its customary norms and sanctions are used as a standard of formal regulations governing norms and sanctions in public life, (d) although indigenous communities prefer formal institution because it has various resources but the level of adherence to indigenous institutions is higher when compared to formal institutions.

In Arnt's view it is said in Solor islands there are social values that always lead and maintain the balance of relations with the highest form Lera Wulan (God), the balance of relations with ancestors and the balance of inter-human and natural relationships. The above view is that every government program/policy should maintain the above social values.

Some of the points of the research and this view basically show a higher level of obedience by the community to the indigenous structure / indigenous institutions this is based on the belief of indigenous communities towards indigenous institutions and structures that can better guarantee the balance of relations between indigenous communities and macro cosmos (gods and ancestors), fellow indigenous communities and the environment. This last comment shows that there is value that society believes in as a guideline and standard of living; therefore policy as a value should also be juxtaposed with the values that have been maintained and maintained by the community. It also means that in general, society has not been very oriented towards the value of efficiency, economy, productivity, and effectiveness as desired by the policy.

\section{Research methodology}

This research was conducted in East Flores Regency which includes 19 sub-districts with the number of villages / villages $=105$ villages / villages. The overall observations include the policy implementing agency (BPMPD = head of agency and 2 staff, head of Cooperative and SME Office and 2 staff, head of Trade and Industry Office and 2 staff, head of Cultural and Tourism Office and 2 staff), street level implementation (District Government, Village Government and Program Implementing Unit) with details of business group and number of members as follows. 
Table 2

Number of Villages, Number of Groups, Number of Members and Business Type

\begin{tabular}{|l|l|l|l|l|}
\hline Year & $\begin{array}{l}\text { Number } \\
\text { of } \\
\text { Villages }\end{array}$ & $\begin{array}{l}\text { Number } \\
\text { of Groups }\end{array}$ & $\begin{array}{l}\text { Number } \\
\text { of } \\
\text { Member }\end{array}$ & $\begin{array}{l}\text { Business Type and Number of Members per Business } \\
\text { Type }\end{array}$ \\
\hline 2017 & 19 & 181 & 1.288 & $\begin{array}{l}\text { Livestock (314), kiosks / traders (246), fishermen } \\
\text { (25), workshop / artisan (43), culinary (21), weaving / } \\
\text { sewing (54), brick making (16), transportation } \\
\text { services (9), agriculture (10), fish baskets (8), } \\
\text { commodity collectors (8) }\end{array}$ \\
\hline 2018 & 45 & 381 & 2.360 & $\begin{array}{l}\text { Livestock (700), trade \& industry (864), fishermen } \\
\text { (128), fish baskets (174), commodity collectors (17), } \\
\text { workshops / furniture (25), transportation services, } \\
\text { photocopy, rental (80), carpentry (151), weaving / } \\
\text { sewing (93) }\end{array}$ \\
\hline 2019 & 41 & 247 & 1.587 & $\begin{array}{l}\text { Livestock (563), trade \& industry (638), services (70), } \\
\text { carpentry / workshop (107), fishermen (76), weaving / } \\
\text { sewing (102), agriculture (23), tourism (8) }\end{array}$ \\
\hline
\end{tabular}

Source: Research Data, 2020

Noticing the data source (target group) that varies above, then each business group is set a sample of $5 \%$, so that the sample size of $=49$ business groups then each business group is determined $5 \%$ of its members to be a source of information: breed $=78$, stalls $/$ traders $=87$, fishermen $=11$, carpentry $=15$, furniture $=3$, services $=9$, fish basket $=9$, weaving tie $=12$, agriculture $=2$, tourism $=$ 1 , commodity collector $=1$, trade $=$ industry $=75$. Thus the informant comes from a member of the business group $=303$ informants. Interviews are conducted using a list of structured interviews with SKPD leaders as well as assigned staff, interviews with street level implementation (Head of District, Village Head and UPK) as well as in-depth interviews with policy target groups, conducted as well as FGD with the relevant agency leaders, village heads and UPK as well as target groups as set out above.

\section{Research Variables}
a. Policy Input Variables
b. Policy Process Variables
c. Policy output variables

\section{Results and discussions}

\subsection{Community economic empowerment program profile}

4.1.1. Goals and organizing

The Golden Gate program is the flagship program of East Flores Regency to encourage the economic development of the community. The basis of the Implementation of the Golden Gate program is The Regent's Regulation of East Flores No. 5 of 2013 on Technical Instructions for The Implementation of the Golden Gate program through Community Economic Empowerment. The Objectives and Objectives of the Golden Gate Program are presented in the following table.

Table 2

Goals and Objectives of The Golden Gate Program of East Flores Regency

\begin{tabular}{|l|l|l|}
\hline Article 2 & \\
\hline Verse 1 & General Purpose & Indicators \\
\hline
\end{tabular}

2020 | Annals of Management and Organization Research / Vol 1 No 2, 123-140 


\begin{tabular}{|c|c|c|}
\hline & a. reducing poverty & percentage of the poor \\
\hline & $\begin{array}{l}\text { b. improving the welfare of the } \\
\text { community }\end{array}$ & \\
\hline \multirow[t]{3}{*}{ Verse 2} & Special Purpose & \\
\hline & a. increase per capita income & per capita income level \\
\hline & $\begin{array}{ll}\text { b. } \begin{array}{l}\text { increase } \\
\text { opportunities }\end{array} & \text { employment } \\
\end{array}$ & open unemployment rate \\
\hline \multicolumn{3}{|l|}{ Article 3} \\
\hline \multirow[t]{3}{*}{ Verse 1} & Target & \\
\hline & $\begin{array}{ll}\text { a. } & \text { development of cooperative } \\
\text { institutional/microfinance } \\
\text { institutions in villages/villages }\end{array}$ & $\begin{array}{l}\text { 1. number of cooperative units } \\
\text { 2. number of units of } \\
\text { microfinance institutions }\end{array}$ \\
\hline & $\begin{array}{l}\text { b. communities in villages/villages } \\
\text { that are involved in productive } \\
\text { economic business groups }\end{array}$ & $\begin{array}{l}\text { 1. } \begin{array}{l}\text { number of new productive } \\
\text { groups }\end{array} \\
\text { 2. } \begin{array}{l}\text { number of new productive } \\
\text { group members }\end{array}\end{array}$ \\
\hline
\end{tabular}

Source: East Flores Regent Regulation No. 5/2013 on Technical Instructions for Implementation of Golden Gate Program

Picture 3

Gold Gate Program Implementing Organization

\begin{tabular}{|c|c|}
\hline \multicolumn{2}{|c|}{ DISTRICT LEVEL COORDINATION TEAM (article 5) } \\
\hline 1. Regional Secretary & 8. Head of Forestry and Plantation Service \\
\hline 2. Head of BAPPEDA & 9. Head of Marine and Fisheries Service \\
\hline 3. Head of BPMD & 10. Head of Industry and Trade Service \\
\hline 4. District Inspector & 11. Head of the Culture and Tourism Office \\
\hline $\begin{array}{l}\text { 5. Head of Cooperatives and Micro, Small } \\
\text { and Medium Enterprises }\end{array}$ & 12. Head of PPKAD office \\
\hline 6. Head of the Food Security Agency & 13. Head of the Investment Office \\
\hline $\begin{array}{l}\text { 7. Head of Agriculture and Animal } \\
\text { Husbandry Service }\end{array}$ & \\
\hline
\end{tabular}

\section{SUB-DISTRICT COORDINATION TEAM (article 8)}

1. Head of District

2. Other Related Elements

3. 3. Head of the Technical Implementation Unit of the Related Service 
1. Village head as Budget User / Lurah as 2. Activity Management Unit (UPK) Budget User Power

\section{Recipient Target Group}

\subsubsection{Implementation of activities}

\section{Fiscal Year 2017}

Up to the evaluation of the implementation of the Golden Gate Program the number of Target Groups (2017-2019) that has received rolling fund assistance as many as 562 Groups with a total of 3,648 members, spread to 64 villages / villages with a total of funds that have been distributed amounting to $\mathrm{Rp} 26$ billion.

\section{Table 4}

Business Type and Number of Group Members (Persons)

\begin{tabular}{|l|l|l|}
\hline No & \multicolumn{1}{|c|}{ Business Type } & \multicolumn{1}{c|}{$\begin{array}{c}\text { Number of Group Members } \\
\text { (Persons) }\end{array}$} \\
\hline 1 & Livestock & 314 \\
\hline 2 & Kiosk or trade & 246 \\
\hline 3 & Fishermen & 25 \\
\hline 4 & Mechanic & 43 \\
\hline 5 & Cake Business & 21 \\
\hline 6 & Weaving / Sewing & 54 \\
\hline 7 & Brick Printing & 16 \\
\hline 8 & Transportation / Ojek Services & 9 \\
\hline 9 & Agriculture & 10 \\
\hline 10 & Fish Basket & 8 \\
\hline 11 & Commodity Collectors & 8 \\
\hline & Total & $\mathbf{1 . 2 8 8}$ \\
\hline
\end{tabular}

Source: BPMD East Flores Regency, 2017

\section{Fiscal Year 2018}

For 2018 the Golden Gate Program was allocated to 45 villages/villages spread across 19 sub-districts. The allocation of funds for 2018 amounting to Rp. 11,250,000,000 (eleven billion two hundred and fifty million rupiah) has been distributed to the accounts of 45 target villages/villages:

Table 5

Business Types and Number of Group Members (People)

\begin{tabular}{|l|l|c|}
\hline \multicolumn{1}{|c|}{ No } & \multicolumn{1}{|c|}{ Bisiness Type } & $\begin{array}{c}\text { Number of Group } \\
\text { Members (People) }\end{array}$ \\
\hline 1 & Livestock & 429 \\
\hline 2 & Kiosk or Trade & 167 \\
\hline
\end{tabular}




\begin{tabular}{|l|l|c|}
\hline 3 & Fishermen & 125 \\
\hline 4 & Fish / Vegetable Basket & 174 \\
\hline 5 & Plantation Comodity Collector & 17 \\
\hline 6 & Furniture/workshop & 25 \\
\hline 7 & Domestic industry & 70 \\
\hline 8 & Ikat Weaving & 63 \\
\hline 9 & Agricultural Equipment Services & 11 \\
\hline 10 & Brick Printing & 17 \\
\hline 11 & Land / Sea Transportation Services & 6 \\
\hline 12 & Agriculture & $\mathbf{2 . 3 6 0}$ \\
\hline & Total & \\
\hline
\end{tabular}

Source: BPMD East Flores Regency, 2018

\section{Fiscal Year 2019}

For 2019 the Golden gate program was allocated to 41 villages/villages spread across 19 sub-districts. The allocation of funds for 2019 is Rp. 10,250,000,000 (ten billion two hundred and fifty million rupiah).

Table 6

Villages, Groups and Number of Implementing Members of the Golden Gate Program 2019

\begin{tabular}{|l|l|l|l|l|l|}
\hline No & Sub-districts & Villages & Groups & Number of Group Members & Fund (Rp) \\
\hline 1 & Wulanggitang & Hewa & 7 & 52 & $250,000,000$ \\
\hline 2 & Ile Bura & Birawan & 10 & 73 & $250,000,000$ \\
\hline 3 & Titehena & Watowara & 8 & 38 & $250,000,000$ \\
\hline 4 & Demon Pagong & Bama & 6 & 24 & $250,000,000$ \\
\hline 5 & Larantuka & Sarotari Utara & 8 & 49 & $250,000,000$ \\
\hline 6 & Ile Mandiri & Lewoloba & 11 & 48 & $250,000,000$ \\
\hline 7 & Tanjung Bunga & Kolaka & 12 & 63 & $250,000,000$ \\
\hline 8 & Lewolema & Sinar Hading & 13 & 83 & $250,000,000$ \\
\hline 9 & Solor Barat & Rotaebang & 10 & 45 & $250,000,000$ \\
\hline 10 & Solor Timur & Lewohedo & 7 & 107 & $250,000,000$ \\
\hline 11 & Solor Selatan & Kenere & 5 & 22 & $250,000,000$ \\
\hline 12 & Adonara Barat & Bukit Seburi II & 9 & 99 & $250,000,000$ \\
\hline 13 & Adonara Timur & Lamatwelu & 18 & 155 & $250,000,000$ \\
\hline 14 & Adonara Tengah & Horowura & 14 & 80 & $250,000,000$ \\
\hline 15 & Klubagolit & Hinga & 7 & 54 & $2,000,000$ \\
\hline
\end{tabular}




\begin{tabular}{|l|l|l|l|l|l|}
\hline 16 & Adonara & Lamahoda & 10 & 93 & $250,000,000$ \\
\hline 17 & Ile Boleng & Lewopao & 4 & 69 & $250,000,000$ \\
\hline 18 & Witihama & Lamablawa & 14 & 87 & $250,000,000$ \\
\hline 19 & Wotan Ulumado & Samasoge & 6 & 30 & $250,000,000$ \\
\hline & Total & & $\mathbf{1 8 3}$ & $\mathbf{1 2 7 1}$ & $\mathbf{4 , 7 5 0 , 0 0 0 , 0 0 0}$ \\
\hline
\end{tabular}

Source: Processed from the East Flores Regency BPMD Report, 2019

\subsection{Analysis of research results}

Be aware that a public policy is always associated with public values. The policy relationship with public values is a chain that moves and carries possible positip or negatip values. Therefore, a defined public policy is not a result of mechanistic thinking that always relies on efficiency, productivity, effectiveness and economy but is the result of an appraisal participatory process that thus can know and balance the value between policy values and social values. It is this rationale that is the basis of the research team's thinking to design a public policy model that can accommodate societal values (with participatory approaches) at the stage of policy input determination, policy process stage, policy external stage, outcome stage, policy benefit stage and policy impact.

\subsubsection{Policy input variables}

Inputs in this policy include:

\begin{tabular}{|c|c|c|c|c|c|}
\hline $\begin{array}{l}\text { Supporting } \\
\text { regulations }\end{array}$ & $\begin{array}{l}\text { Target group } \\
\text { requirements }\end{array}$ & $\begin{array}{l}\text { Organizational } \\
\text { structure }\end{array}$ & $\begin{array}{l}\text { Business } \\
\text { administration }\end{array}$ & Management & Guidelines \\
\hline $\begin{array}{l}\text { Head of } \\
\text { District } \\
\text { decision, } \\
\text { village } \\
\text { regulations, } \\
\text { Headmen } \\
\text { Decisions/Re } \\
\text { gulations, } \\
\text { fund } \\
\text { assistance, } \\
\text { revolving } \\
\text { funds and } \\
\text { installments, } \\
\text { business } \\
\text { management } \\
\text { coaching and } \\
\text { results } \\
\text { marketing, } \\
\text { coaching of } \\
\text { members } \\
\text { mental } \\
\text { attitudes, }\end{array}$ & $\begin{array}{l}\text { Formal and } \\
\text { special terms, } \\
\text { terms are } \\
\text { made and } \\
\text { agreed upon } \\
\text { by the group } \\
\text { and its } \\
\text { members }\end{array}$ & $\begin{array}{l}\text { Chairman, vice } \\
\text { chairman, } \\
\text { treasurer, } \\
\text { member. } \\
\text { Special } \\
\text { coaching } \\
\text { program for } \\
\text { group } \\
\text { managers }\end{array}$ & $\begin{array}{l}\text { Business } \\
\text { group } \\
\text { administration } \\
\text { system guide, } \\
\text { business } \\
\text { recording } \\
\text { system, } \\
\text { business } \\
\text { reporting } \\
\text { system, }\end{array}$ & $\begin{array}{l}\text { Mentoring } \\
\text { and coaching } \\
\text { by relevant } \\
\text { agencies }\end{array}$ & $\begin{array}{l}\text { Business } \\
\text { implement } \\
\text { ation } \\
\text { guide }\end{array}$ \\
\hline
\end{tabular}

a) Supporting Rules: Policy input (supporting rules) is one of the important variables and determines policy performance. In this study analyzed some much needed policy inputs; among them: (1) decisions of the camat and the village chief. In every sub-district located 
in East Flores Regency, based on document studies and interviews (interviews with the district attorney, village heads and with the head of the business group) shows the absence of any governing decisions about the governance of the business group mainly related to the balance of the value of policy performance with the values of local wisdom. Likewise, with the help of funds, revolving funds and member installments. In addition, no business management norms and marketing of business results including the coaching of members' mental attitudes. The vacancy of one of these supporting conditions resulted in both business groups and group members conducting business based on their own will the absence of business guidelines/guidelines issued by the authorized parties and the absence of schedule/calendar of activities resulting in the group and group members freely determining the type of business and business time. Furthermore, based on interviews with Indigenous people Keba Ba'i Pito it is said that in daily life every member of the business group usually performs a ritual / ceremonial purpose other than for the smooth running of his efforts and to establish a harmonious relationship with Lera Wulan (the highest form), harmony of relations with ancestors and relations with the surrounding natural environment. This ritual is usually performed in the morning and evening at the place / location of the business and usually the media used to communicate with such parties such as: betel nut, arak (local liquor), cigarettes / tobacco which if calculated around Rp. 2000.for each time. If the group members face problems in their business is generally solved in private and usually done through/using traditional media and tradition if there is a problem in the business then the solution is very dependent on the individual and usually done through traditional rituals that budget around $\mathrm{Rp} .500,000$, that is usually for relatively minor problems such as: equipment damage, under-selling, or the onse of certain failures. Traditional rituals performed generally in order to establish a relationship with Lera Wulan tana Ekan (the highest form and ruler of the earth), with ancestral spirits and with other powers believed to be around the lives of her and her family; as for major problems such as life-threatening accidents and agencies often require a fairly targeted budget of --around Rp. 500,,- --- is also for the same purpose of maintaining the balance of relations with these parties. Furthermore, according to this indigenous figure, usually individuals who face this problem use funds /money assistance from empowerment programs that they receive (interview with Paulus Radja Weking, August 21, 2020 in Mudakaputu Village). An analysis of expenses for ritual/ceremonial expenses can be found in table 13 below. (2) fund assistance and revolving funds; Funding assistance from other parties until the time of this research has not been done, while it is related to the rolling funds so far run based on the guidelines set out in the regent's regulations but in reality the rolling funds have not been optimally taken place as a result of arrears carried out by members as well as by the group managers who lend installment funds of group members to other parties.

b) Group Terms: Although, regulatoryly established the terms of the business group members and the terms of the formation of the group but in the formation of the business group the mechanism is self-regulated by the village government. The consequence of forming a business group like this is the opening up of nepotism and collusion. The creation of a pattern of forming a 'father-son' group (patron - klain) --- the chairman of the business group selects members of the business group based more on consideration of klen /tribe and instead of on business experience and business type equality. Based on the results of an interview with the chairman of the Keba Baipito Indigenous Institute, it is said that the formation of business groups like this is basically good because tribal members are easier to control based on tribal values only in trying/activity tribal members will be ambiguous especially towards tribal rules and trying behavior.

c) Organizational Structure: with regard to the structure of the business group the results of the research show that all business groups have had the appropriate organizational structure of the business as set out in the regent's decision as conveyed at the beginning of this paper. Although, the structure and organization of the business exists but in reality there is no working relationship between structures as stipulated in the decree. Based on the results of interviews with the head of Cooperatives and SMEs east Flores Regency it is said that almost all business groups that make decisions and determine the state of the 
business are the chairman of the group and sometimes the co-chairman of the treasurer. Furthermore, it is said that special coaching for business group trustees does not take place. This can be seen from the form of reports or accounting of the group's business. Most business groups do not have the correct business bookkeeping and impress the origin; meanwhile, the literacy capability of the group members against various reports of group activities, especially with regard to business financial statements is relatively low.

d) Business Administration: Related to business administration can be said not well organized. Archival management has not been seen as a system of control over business or group behavior. This can be seen from the frequent inconsistance of the relationship between the chairman, treasurer and members of the group with regard to the smooth deposit of loans and rolling funds. The consequence of the absence of efforts to strengthen (input) to the administrative aspects of such businesses is the difficulty in analyzing the performance of the group including the performance of policies that directly affect the evaluation of economic empowerment policies that have been set.

e) Management: policy input through strengthening management which in this case is done through group mentoring and business management conducted by related inststansi so far has not been done in a patterned and scheduled way. It is acknowledged that it was done through a general briefing at the time of the visit from the relevant agencies but has not been done in a planned manner.

Guidelines: guidelines in this case in the form of business guidance for business groups as well as members of business groups have not been found; as a result each business group sets its own norms/rules while business group members feel unattached to the group's rules because there are differences with the norms/rules in the other business group even though they are in one village.

Table 13 below shows data relating to ritual/ceremonial costs carried out by each member of the business group in order to maintain a harmonious, balanced, harmonious relationship with Lera Wulan Tana Ekan, ancestors, and the surrounding natural environment

Table 13

Business Type, Number of People and Amount of Ritual Cost every Month (Rp)

\begin{tabular}{|l|l|c|c|}
\hline No & Business Type & Number (Person) & Monthly fee (rp x 22 hr) \\
\hline 1 & Livestock & 429 & 4.719 .000 \\
\hline 2 & Kiosk or Trade & 167 & 1.837 .000 \\
\hline 3 & Fishermen & 125 & 1.375 .000 \\
\hline 4 & Fish/Vegetable basket & 174 & 1.914 .000 \\
\hline 5 & Plantation Comodity Collector & 17 & 187.000 \\
\hline 6 & Furniture/Workshop & 25 & 275.000 \\
\hline 7 & Domestic Industry & 70 & 770.000 \\
\hline 8 & Ikat Weaving & 63 & 693.000 \\
\hline 9 & Agricultural Equipment Services & 11 & 121.000 \\
\hline 10 & Brick Printing & 17 & 275.000 \\
\hline 11 & Land/sea transportation service & 25 & 66.000 \\
\hline 12 & Agriculture & 6 & $\mathbf{1 2 . 4 1 9 . 0 0 0}$ \\
\hline & Jumlah & $\mathbf{1 . 1 2 9}$ & 2.000 \\
\hline
\end{tabular}

2020 | Annals of Management and Organization Research / Vol 1 No 2, 123-140 
Source: Research Results, 2020

Information that can be conveyed with respect to table 13 data, it appears that each member of the group continues to perform rituals/ ceremonial aimed at being safe and safe in trying. As conveyed above that every day members of the business group spend rp. 500,- and furthermore if multiplied by the number of working days a month $=22$ working days then the amount of expenses for ritual/ceremonial expenses for all types of businesses per month amounts to Rp. 12,419,000.- (twelve million four hundred and nineteen thousand rupiah). This considerable spending condition will then be confirmed by arrears and installments and installments of business group members.

\subsubsection{Policy process variables}

With regard to process variables, the focus of research is directed at aspects as conveyed in the table below.

\begin{tabular}{|l|l|l|l|l|}
\hline Strengthening & Empowerment & $\begin{array}{l}\text { Training / } \\
\text { mentoring }\end{array}$ & Compliance & Sanctions \\
\hline $\begin{array}{l}\text { Procurement of } \\
\text { business } \\
\text { support } \\
\text { facilities, } \\
\text { funding } \\
\text { assistance, } \\
\text { business } \\
\text { partnerships, } \\
\text { production and } \\
\text { marketing } \\
\text { exhibitions }\end{array}$ & $\begin{array}{l}\text { Expansion of } \\
\text { business network, } \\
\text { business } \\
\text { partnership, } \\
\text { marketing } \\
\text { expansion, } \\
\text { production } \\
\text { management } \\
\text { training }\end{array}$ & $\begin{array}{l}\text { Schedule of } \\
\text { training and } \\
\text { mentoring and } \\
\text { monitoring of } \\
\text { businesses, } \\
\text { business group } \\
\text { workshops }\end{array}$ & $\begin{array}{l}\text { Group and } \\
\text { business } \\
\text { discipline } \\
\text { guidelines, } \\
\text { fostering } \\
\text { awareness of } \\
\text { business group } \\
\text { members }\end{array}$ & $\begin{array}{l}\text { Punishment } \\
\text { and praise }\end{array}$ \\
\hline
\end{tabular}

Based on the results of the study with regard to the variables and indicators set out above, can be submitted as follows. (a) during the program implementation process, the group and group members have never received assistance or support in the form of business support facilities, financial assistance from other parties and or business partners as well as invitations from the government (related agencies) to engage in introducing or showing off the business results of group members or groups. (b) in the context of the empowerment policy process, in this case related to the expansion of the business network, business partnerships, marketing expansion, production management training; data from the study shows that there has not been any activity or effort to expand the business network, business partnerships, marketing expansion or production management training. Based on the results of interviews with the chairman of the chicken cattle group can be conveyed that the procurement of broiller, chicks and medicines (vaccines) has been personally attempted by each farmer as well as the results (products) distributed and marketed still carried out privately. Furthermore, it was said that there has never been any training in relation to management so far the pattern of farmer activity has not changed and relies solely on personal training. The consequence of such process conditions is that neither the activities of the business group nor the members of the business group seem to be developing (static).

Furthermore, related to schedule training and business mentoring and monitoring, business group workshops, based on the results of document studies show unprecedented workshops, training and scheduled seizures for business groups.

Process variables also relate to compliance; compliance/obedience of group members to group and business discipline guidelines, fostering awareness of business group members. Based on data collected about this sub-variable was not found. In each business group there are no rules, norms or guidelines agreed by all members of the group with regard to the level of adherence of members to the life of the group. The further consequence of such conditions is that each member of the 
group is personally free to do and or does not do anything to do with the interests and sustainability of the group such as orderly towards installments, the field of business does not switch (keep trying according to the field of business proposed in the proposal.

Sanctions in the form of fines for members who pay in installments or switch activities / businesses are basically not regulated in the group agreement. New sanctions are imposed after the awareness/discovery of most members in installments and rolling funds. The sanctions found in the field are in the form of public announcements by disseminating information in writing or through loudspeakers (Toa) about members who are down the installments, the amount and the rollout funds that are not deposited into the group's coffers in each monthly activity of the group's administrators conducted in the village head office. Despite efforts to improve the process and performance of the policy, this social sanctions and penalties do not cause deterrent effects for business group members. For details can be seen in the following table.

Table 14

Business Type, Number of People and Members of The Group Those Installments

\begin{tabular}{|l|l|c|c|}
\hline No & Bisiness Type & Number of People & $\begin{array}{l}\text { Members of The Group } \\
\text { Those Installments }\end{array}$ \\
\hline 1 & Livestock & 429 & 198 \\
\hline 2 & Kiosk or Trade & 167 & 85 \\
\hline 3 & Fishermen & 125 & 97 \\
\hline 4 & Fish/vegetable basket & 174 & 86 \\
\hline 5 & Plantation Commodity Collectors & 17 & 11 \\
\hline 6 & Furniture/Workshop & 25 & 48 \\
\hline 7 & Domestic industry & 70 & 22 \\
\hline 8 & Ikat Weaving & 63 & 5 \\
\hline 9 & Agricultural Equipment Service & 11 & 8 \\
\hline 10 & Brick Printing & 17 & 3 \\
\hline 11 & Land/Sea Transportation Service & 25 & $\mathbf{5 7 3}$ \\
\hline 12 & Agriculture & 6 & $\mathbf{1 . 1 2 9}$ \\
\hline & Total & & 11 \\
\hline
\end{tabular}

Source: Research Results, 2020

The data table above shows that each type of business of its members support installment installments and revolving fund installments; it also reads that about 50\% of members are insured or in installments and rolling.

\subsubsection{Policy output variables}

Policy performance analysis with respect to output variables can be viewed in the following table.

\begin{tabular}{|l|l|l|l|}
\hline Strengthening & Empowerment & Training/mentoring & Management \\
\hline $\begin{array}{l}\text { Standardization of } \\
\text { output, , expansion of } \\
\text { marketing network }\end{array}$ & $\begin{array}{l}\text { Quality and quantity of } \\
\text { output coaching, quality } \\
\text { control management }\end{array}$ & $\begin{array}{l}\text { Post-production training, } \\
\text { production packing, } \\
\text { sales efficiency }\end{array}$ & $\begin{array}{l}\text { Implementation of } \\
\text { monitoring, product } \\
\text { certification }\end{array}$ \\
\hline
\end{tabular}


and business partners, $\quad$ training, expansion of

expansion of business stakeholder group(s)

raw material support

Policy output generally indicates the performance of the entire policy process. Based on the results of the study with regard to the variables and indicators set out above, can be submitted as follows. (a) During the program implementation process, the group and members of the group have never received assistance or support in the form of business support facilities, financial assistance from other parties and or business partners as well as invitations from the government (related agencies) to engage in introducing or showing off the business results of group members or groups, (b) With regard to the variable process in this case empowerment can be said that based on the results of interviews with the Head of District, village heads and with related agencies (Office of Industry and Trade) can be conveyed that there has never been an effort to expand the business network, business partnerships, marketing expansion and production management training for business groups and business group members. Furthermore, based on observations at the research site found only members of the group who tried individually / independently instead of in the form of business groups. Furthermore, based on an interview with one of the beneficiaries of empowerment assistance in the field of livestock is said that so far the produce is marketed it self the buyer of the product is sought personally and not through a network regulated by the business group or by the relevant agency.

a. Reinforcement; Standardize output. expansion of marketing networks and business partners, expansion of business raw material support. Products/outputs derived from various types of businesses produced by business groups mainly related to product standardization efforts, expansion of business network and business partners as well as expansion of raw material support up to this research activity is carried out not taking place. Based on the results of interviews with the chairman of the plantation commodity collecting business group, the chairman of the meubler business group, the chairman of the fishing business group, obtained information that so far all business groups only produce (output) and have never been briefed / coached by related agencies (such as the Trade and Industry Office or cooperative office) related to the quality of products let alone related to product standards. Each business group only markets its product results directly and never make efforts to select the quality of the product and the group members never know and understand the standard of the product such as: time (production length), size / size, condition of the product let alone related to product packaging / packing. Such a consequence is that the selling value does not change so that the income of group members tends to remain.

b. Empowerment; Quality and quantity of output coaching, quality control management training, expansion of stakeholder group(s); In the context of production management and marketing management it is important to conduct quality and quantity of output, quality control management training and the expansion of stakeholder group(s). The performance of policies, especially economic empowerment policies, is also determined by the empowerment aspect. In general it can be said that the output/product of economic empowerment policies of the community often ignores this aspect. The consequence is that in business groups and business group members do not wake up to the atmosphere of product competition all types of products remain the same quality and there are no product variations. This statement is in line with the opinion of the chairman of the meubler business group as well as the chairman of the chicken cattle group; so far the quality of the product has remained that has never changed this is the case because neither the business group nor the group members have ever obtained a touch related to the quality of the product.

c. Training / mentoring; Post-production training, production packing, sales efficiency. Policy output in the form of post-production training/mentoring, sales efficiency in general can be said to have never taken place. This condition is actually the same as some of the subvariables mentioned and commented above.

d. Management; Implementation of monitoring, product certification. The implementation of monitoring related to output performance based on the results of interviews with business 
group members as well as several business group leaders can be said to have not been implemented, as well as with regard to product certification.

e. Some of the points of the research results with regard to the performance of the policy output that has been submitted above can be commented that the overall output of the policy is submitted into the affairs and responsibilities of each business group specifically to the members of the business group

\section{Conclusion}

Based on the data of the research results as well as the results of the analysis conducted in the previous section, the following will be presented some points concluding about the results of this study.

1. The overall economic empowerment policy process of the community is very impressed using economic logic that relies on efficiency, rationality, effectiveness by ignoring patterns of community behavior as well as local wisdom values in its involvement in economic aspects (empowerment of),

2. Steet level implmentation seems less flexible in the sense that it always relies on bureaucratic interactions and in the process of implementing policies (input --- process --- output) has not been integrated.

3. Policy input variables, especially with regard to strengthening aspects, empowerment aspects and aspects of compliance still require serious attention by authorized parties such as the camat and village head /lurah so as to demand a certain level of supervision from business groups as well as business group members.

4. Policy inputs have not regulated the alignment of values, especially economic values such as efficiency, effectiveness, ratio with local community values/wisdom.

5. Policy process variables, specifically related to the procurement of business support facilities, business funding assistance and business partnerships have not received attention.

6. Aspects of business network expansion, marketing expansion, and production management training have not been used as strength and empowerment policy process.

7. Policy output variables such as product standardization, expansion of business networks and expansion of support in raw materials are among the keys to the success of the implementation program but have not received attention.

8. There is a need for integration efforts and aligning economic values with local wisdom values in community economic empowerment programs.

9. The role of street level implementation should be improved so that it can be more flexible with the demands and needs of business groups and business group members.

10. It is hoped that there will be constructive efforts made for strengthening and variable policy inputs.

11. Efforts should be made to provide support with regard to business facilities, business partnerships, production exhibitions and marketing as an integral part of the economic empowerment policy process.

12. It is necessary to standardize products, expand business networks and expand support in raw materials which are among the keys to the identity of policy outputs.

\section{Limitation and study forward}

This study only discusses Evaluation of Community Economic Building Movements Policy In East Flores District. Researchers suggest that future researchers can do better research with better data collection methods such as interviews. This would complement the lack of an important view of policy evaluation not addressed in this study.

\section{References}

BPMD Kabupaten Flores Timur. (2017). Data jenis usaha dan jumlah anggota kelompok.

BPMD Kabupaten Flores Timur. (2018). Data jenis usaha dan jumlah anggota kelompok.

BPMD Kabupaten Flores Timur. (2019). Desa, kelompok dan jumlah anggota pelaksana program golden gate 2019. 
BPMPD Kabupaten Flores Timur dan UNDANA Research Institute. (2015). Evaluasi pelaksanaan program gerakan pembangunan ekonomi masyarakat di Kabupaten Flores Timur.

BPMPD Kabupaten Flores Timur. (2019). Jumlah desa, jumlah kelompok dan jumlah anggota kelompok dan jumlah dana program gerbang emas.

Bustanuddin, Agus. (2007). Agama dalam kehidupan manusia. Jakarta: Grafindo Persada

Fernandez, Dominikus \& Hironnymus Jati. (2010). Sikap komunitas adat Pranata Adat Keba Bai Pito terhadap organisasi pemerintah desa menurut PP 72/2005 tentang desa (Studi kasus di kecamatan Ile Mandiri Kabupaten Flores Timur)

Hilman Hadikusuma. (2003). Hukum waris adat. PT. Citra Aditya Bakti. Bandung

Jati, Hironnymus, Indri Astuti, Dominikus Fernandez. (2015). Implementasi inovasi program gerakan membangun ekonomi masyarakat (gerbang emas) dalam meningkatkan pendapatan usaha mikro kecil di Kabupaten Flores Timur. Laporan Hasil Penelitian Hibah Bersaing KemenRistekDikti

Koentjaraningrat. (1985). Pengantar ilmu antropologi. Rineka Cipta, Jakarta

Marpaung, Parlindungan. (2000). Analisis perubahan nilai sosial budaya dan pengaruhnya terhadap pembangunan wilayah di kecamatan Pangururan Kabupaten Tapanuli Utara. Program Pasca Sarjana USU, Medan.

Pelly, Usman. (1994). Teori-teori ilmu sosial budaya. Departemen Pendidikan dan Kebudayaan, Jakarta.

Peraturan Daerah Kabupaten Flores Timur nomor 5 Tahun 2013 Tentang perubahan atas peraturan daerah Kabupaten Flores Timur nomor 12 tahun 2011 tentang retribusi jasa umum.

Sartika Ika. (2015). Evaluasi kebijakan pemberdayaan nelayan. Jurnal IPDN, 1(2).

Undang-Undang Nomor 23 Tahun 2014 tentang Pemerintahan Daerah. 